\title{
Structure of 1,5-benzodiazepinones in the solid state and in solution: Effect of the fluorination in the six-membered ring
}

\author{
Marta Pérez-Torralba ${ }^{1}$, Rosa M. Claramunt ${ }^{* 1}$, M. Ángeles García ${ }^{1}$, \\ Concepción López ${ }^{1}$, M. Carmen Torralba ${ }^{2}$, M. Rosario Torres ${ }^{2}$, Ibon Alkorta ${ }^{3}$ \\ and José Elguero ${ }^{3}$
}

\section{Full Research Paper}

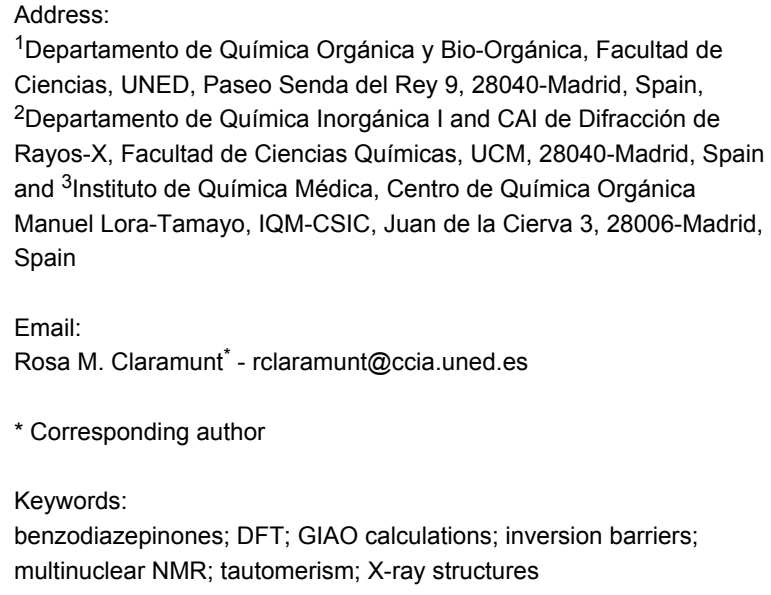

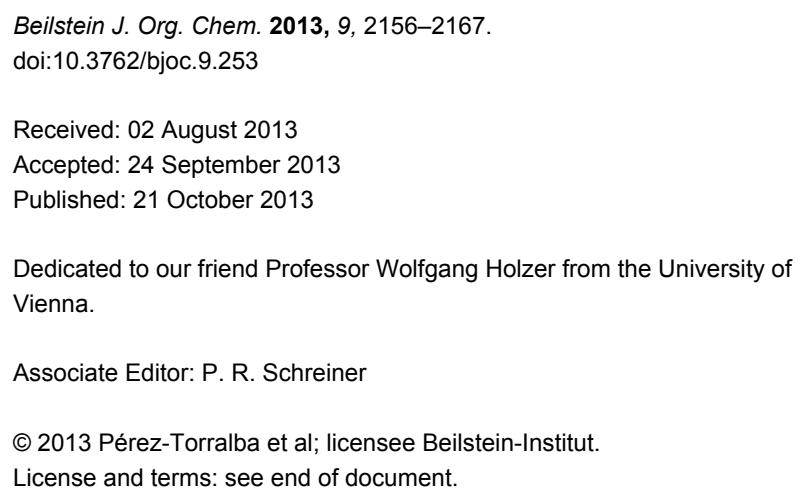

\begin{abstract}
Two novel tetrafluorinated 1,5-benzodiazepinones were synthesized and their X-ray structures determined. 6,7,8,9-Tetrafluoro-4methyl-1,3-dihydro-2H-1,5-benzodiazepin-2-one crystallizes in the monoclinic $P 2{ }_{1} / c$ space group and 6,7,8,9-tetrafluoro-1,4dimethyl-1,3-dihydro-2H-1,5-benzodiazepin-2-one in the triclinic $P-1$ space group. Density functional theory studies at the B3LYP/6-311++G(d,p) level were carried out on these compounds and on four non-fluorinated derivatives, allowing to calculate geometries, tautomeric energies and ring-inversion barriers, that were compared with the experimental results obtained by static and dynamic NMR in solution and in solid state.
\end{abstract}

\section{Introduction}

In our previous paper [1] we already reported the relevance of 1,5-benzodiazepine derivatives in central nervous system pathologies as well as for other applications in medicinal chemistry [2-6], the most important is clobazam (7-chloro-1-methyl5-phenyl-1 $H$-1,5-benzodiazepine-2,4(3H,5H)-dione, Figure 1).
As a continuation of our research program on the synthesis, spectroscopic and biological properties of 1,5-benzodiazepine derivatives as well as their calculated parameters, we report in the present publication the experimental and theoretical studies of 1,5-benzodiazepinones 1-6; note that only compounds $\mathbf{1}$ and 


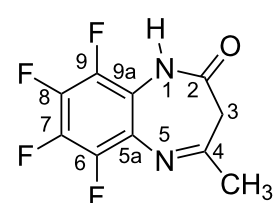

1<smiles>CN1C(=O)CC(=O)N(c2ccccc2)c2cc(Cl)ccc21</smiles><smiles>CC1=Nc2c(F)c(F)c(F)c(F)c2N(C)C(=O)C1</smiles>

2

clobazam<smiles>CC1=Nc2ccccc2NC(=O)C1</smiles>

3<smiles>O=C1CC(c2ccccc2)=Nc2ccccc2N1</smiles><smiles>CC1=Nc2ccccc2N(C)C(=O)C1</smiles><smiles>CN1C(=O)CC(Cc2ccccc2)=Nc2ccccc21</smiles>

Figure 1: The six 1,5-benzodiazepinones discussed in this paper together with clobazam.

$\mathbf{2}$ are new; for compounds 3-6 we used literature data together with new computational results.

\section{Results and Discussion Synthesis}

6,7,8,9-Tetrafluoro-4-methyl-1,3-dihydro-2H-1,5-benzodiazepin-2-one (1) was prepared in $63 \%$ yield by the reaction of 1,2-diamino-3,4,5,6-tetrafluorobenzene with ethyl acetylacetate (ethyl 3-oxobutanoate) following the literature procedure to prepare 3 [7] (Scheme 1). Further treatment with iodomethane under basic conditions afforded 6,7,8,9-tetrafluoro-1,4dimethyl-1,3-dihydro-2H-1,5-benzodiazepin-2-one (2) in $80 \%$ yield.

\section{Geometries}

The geometries of two related structures together with their codes as reported in the Cambridge Structural Database [8,9] are shown in Figure 2.

Compound 1 crystallizes in the monoclinic $P 2{ }_{1} / c$ space group containing one molecule per asymmetric unit (Figure 3; the numbering used in the crystallographic part is different from that of Figure 1). The bonding distances and angles agree with the electronic distribution according to one amide group on the $\mathrm{C} 1$ atom and one double bond, C3-N2, (tautomer a in Figure 7). The molecule is not planar due to the folding of the sevenmembered ring with $\mathrm{C} 1, \mathrm{C} 2$ and $\mathrm{C} 3$ out of the plane defined by

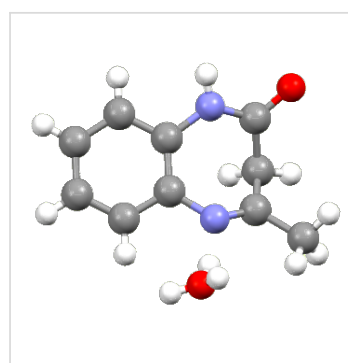

TUPSAZ

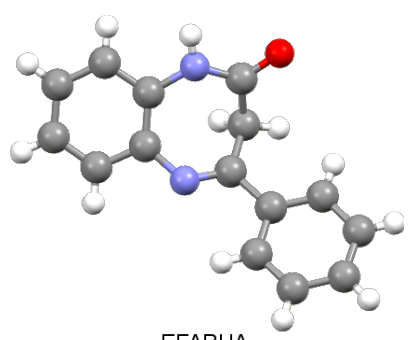

EFARUA
Figure 2: The X-ray structures of 3a (TUPSAZ), 5a (EFARUA). In TUPSAZ there is a disordered water molecule.

the aromatic ring and the nitrogen atoms. The dihedral angles between this plane and those formed by the C1N1O1 and $\mathrm{N} 2 \mathrm{C} 3 \mathrm{C} 8$ atoms are $35.4(2)^{\circ}$ and $41.7(2)^{\circ}$, respectively.

These molecules are linked forming dimers by symmetric hydrogen bonds between the amide group and the carbonyl oxygen atom of an adjacent one (distances $\mathrm{N} 1 \mathrm{H} 1 \cdots \mathrm{O} 1$ ' 1.932(2) $\AA$ and $\mathrm{N} 1 \cdots \mathrm{O} 1 ' 2.877(2) \AA$; angle NHO $\left.162.7(1)^{\circ}\right)$. These dimers interact by double intermolecular F-F contacts between the F5 of a molecule and the F6 of a neighboring one (distance 2.875(2) A) giving rise to a zigzag chain in the [10-1] direction (Figure 4 ). These chains are stacked by a partial $\pi-\pi$ overlapping between the aromatic rings with a shortest distance of 3.19(1) $\AA$.<smiles>CCOC(=O)CC(C)=O</smiles><smiles>CC1=Nc2c(F)c(F)c(F)c(F)c2NC(=O)C1</smiles>

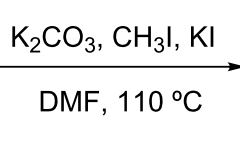
$\frac{\mathrm{K}_{2} \mathrm{CO}_{3}, \mathrm{CH}_{3} \mathrm{l}, \mathrm{KI}}{\mathrm{DMF}, 110^{\circ} \mathrm{C}}$<smiles>CC1=Nc2c(F)c(F)c(F)c(F)c2N(C)C(=O)C1</smiles> 


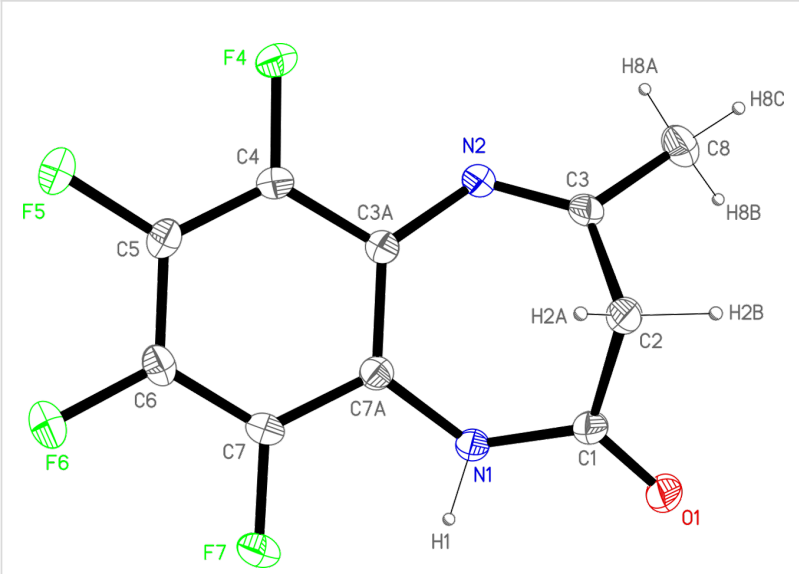

Figure 3: ORTEP plot (30\% probability) of 1, showing the X-ray labeling of the asymmetric unit.

Compound 2 crystallizes in the triclinic $P-1$ space group containing one molecule per asymmetric unit (Figure 5). As for compound $\mathbf{1}$, the molecular geometry corresponds to tautomer a. The seven-membered ring is also folded with dihedral angles between the aromatic ring and $\mathrm{C} 1 \mathrm{~N} 1 \mathrm{O} 1$ of $44.1(3)^{\circ}$ and with $\mathrm{N} 2 \mathrm{C} 3 \mathrm{C} 8$ of $43.2(3)^{\circ}$. This higher values compared to compound 1 indicate a greater deformation in the seven-membered ring owing to the presence of the $N$-methyl substituent.

The $N$-methylation prevents the dimerization by hydrogen bonding leading to a very different packing. Therefore, the most significant intermolecular interaction is the $\mathrm{F}-\mathrm{F}$ contact between the F4 and F7 atoms of adjacent molecules (distance 2.669(3) $\AA$ ) giving rise to chains along the $b$ axis (Figure 6). Each chain is placed antiparallel to the following one in order to minimize the steric hindrance of the groups out of plane. The two chains interact by $\pi-\pi$ overlapping between their aromatic

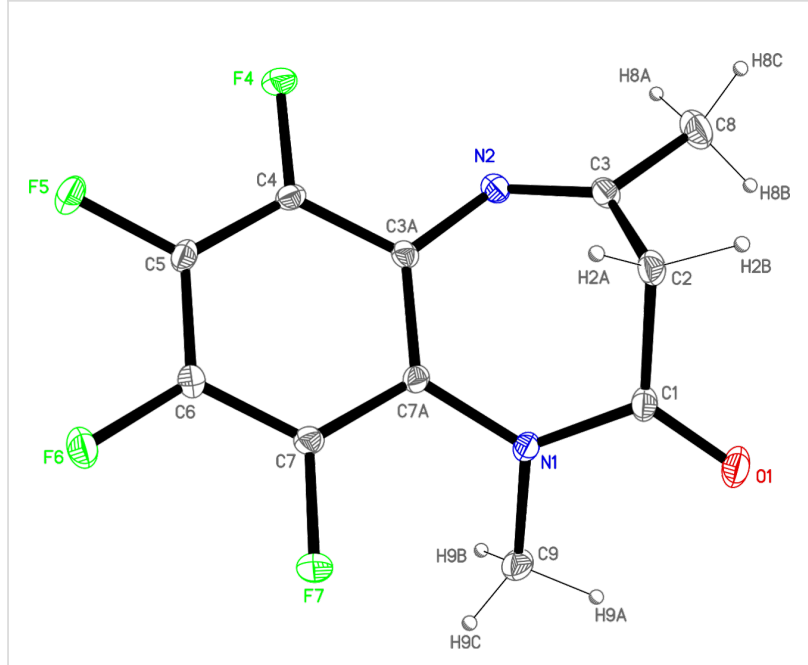

Figure 5: ORTEP plot (20\% probability) of 2, showing the X-ray labeling of the asymmetric unit.

rings, with a shortest distance of 3.35(1) $\AA$. The so formed double chains are isolated because of the above-mentioned steric reasons.

We compared the geometries of compounds 3 (TUPSAZ) $[8,10]$ and 5 (EFARUA) [8-10] (Figure 2) with those determined in the present work, 1 and $\mathbf{2}$. To describe the folding of the sevenmembered ring we used the distance $d$ in $\AA$ between the methylene carbon and the plane defined by the benzene ring. These values are $1.36 \AA$ (3), $1.26 \AA$ (5), $1.33 \AA$ (1) and $1.57 \AA$ (2), thus the 1,5 -benzodiazepinone with a 4 -methyl ring, $\mathbf{3}$, is more bent than that with a 4-phenyl ring, 5. More significant for the present work, the $N$-methyl substituent folded considerably the ring, compare $\mathbf{2}$ with $\mathbf{1}$, this being related to the inversion process discussed below.

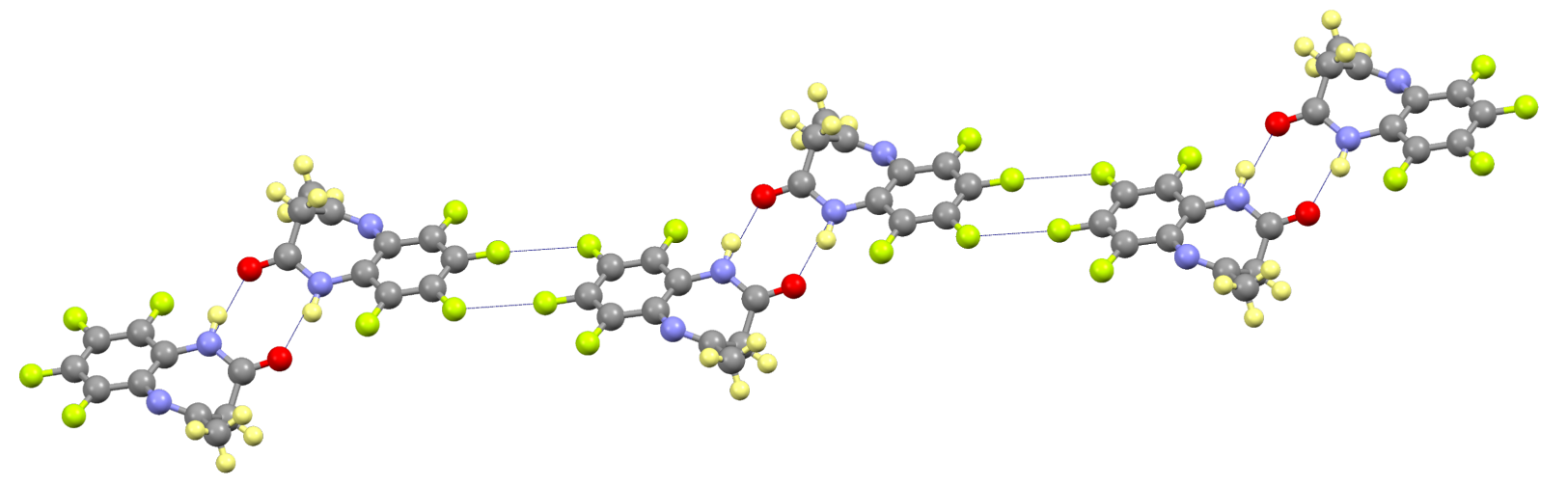

Figure 4: View of the zigzag chain formed in 1, showing the $\mathrm{H}$-bond and F-F interactions. 


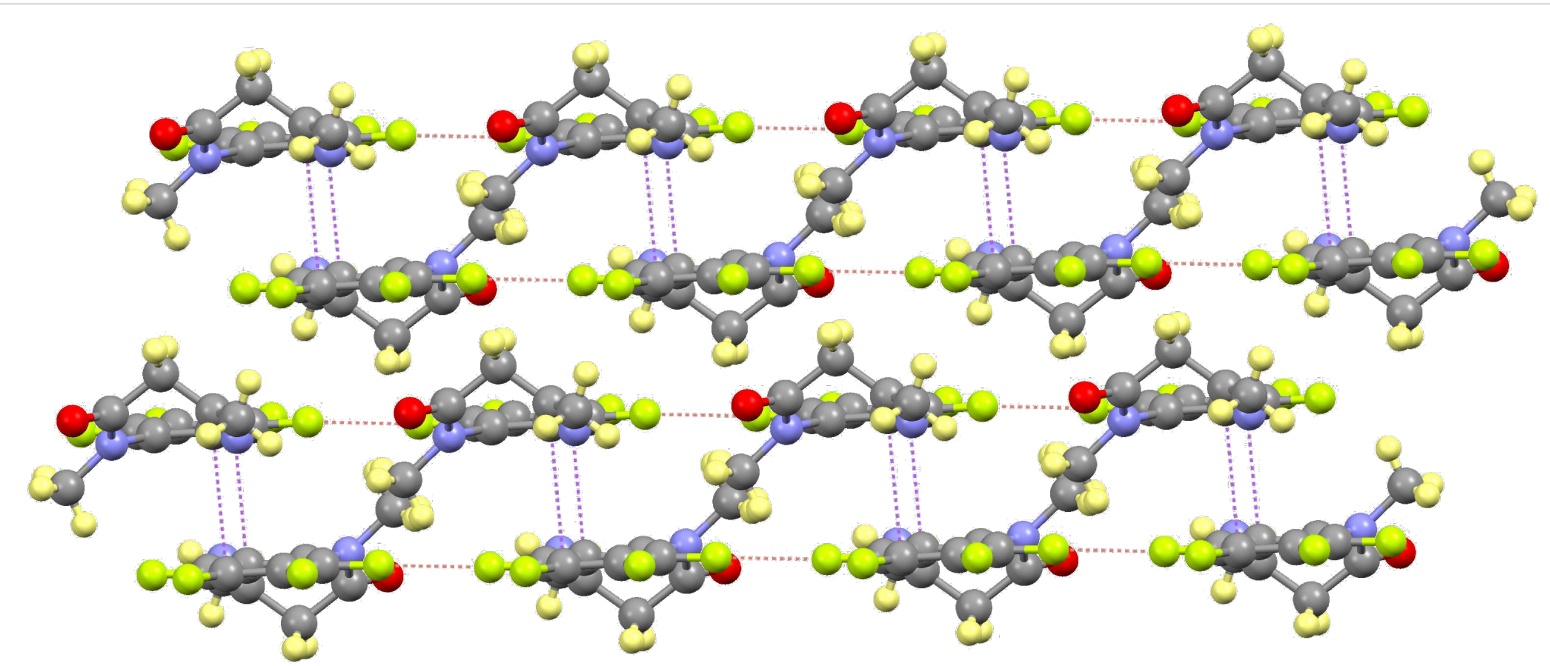

Figure 6: Packing of 2 showing the F-F contacts along the chain (orange) and the $\pi-\pi$ interactions that form the double chain (violet).

\section{Energies and tautomerism}

For the $1 H$-derivatives five possible tautomers exist while for the $N$-methyl ones only three different tautomers are possible (Figure 7).

Mannschreck et al. already concluded in 1967 that $\mathbf{3}$ has the structure 3a based on a methylene signal at $3.14 \mathrm{ppm}$ [11]. This is also compatible with tautomer $\mathbf{3 d}$ but considering that amides never exist as imidic acids, Mannschreck's conclusion is certainly right. Varma et al. reported in 2008 that the reaction between $o$-phenylenediamine and methyl acetylacetate yields the methoxy derivative 7 (Figure 8) without any reported proof [12]. In a subsequent paper they reported that the reaction of $o$-phenylenediamine using ethyl acetylacetate instead of methyl acetylacetate yielded the expected diazepinone that they represent using the tautomer 3d again without any reported proof, neither in the main text nor in the supplementary data [13].

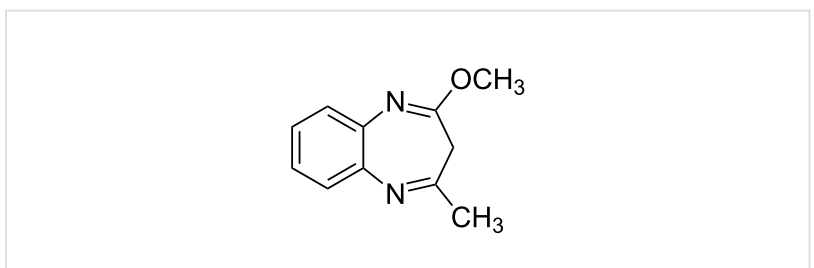

Figure 8: 2-Methoxy-4-methyl-3H-1,5-benzodiazepine (7).

A comprehensive theoretical study of the tautomerism of $\mathbf{3}$ was carried out by Okovytyy et al. in 2010, including monoethanol and diethanol solvates as well as dimeric forms [14] (they do not consider tautomer $3 \mathbf{e})$. In the gas phase their relative energies $\left(\right.$ in $\mathrm{kJ} \mathrm{mol}^{-1}$ ) are: $\mathbf{3 a}(0.0)>\mathbf{3 b}(14.6)>\mathbf{3 d}(48.5)>\mathbf{3 c}$ (93.4) and with an ethanol molecule they are: $\mathbf{3 a}(0.0)>\mathbf{3 b}$ $(0.6)>3 \mathbf{d}(51.3)>\mathbf{3 c}(70.0)$. The great stabilization of $\mathbf{3 b}$ due to ethanol does not correspond to that observed by<smiles>[R]C(C#C)=CC(=O)NN1c2ccccc2N=C([R])CC(=O)Nc2cc([R])ccc21</smiles><smiles>[R]C1=Nc2ccc([R])cc2N(C)C(O)=C1</smiles>

Figure 7: The different tautomers in the $1 H$ and 1-methyl series. 
Mannschreck in $\mathrm{CDCl}_{3}$ [11]. Our calculations (gas phase) are reported in Table 1 .

Table 1: Relative stabilities in $\mathrm{kJ} \mathrm{mol}^{-1}$ of the different tautomers of compounds shown in Figure 1 and Figure 7.

\begin{tabular}{llllll} 
Compound & a & b & c & d & e \\
\hline $\mathbf{1}$ & 0.0 & 9.0 & 90.0 & 45.8 & 55.0 \\
$\mathbf{2}$ & 0.0 & 18.6 & 99.7 & - & - \\
$\mathbf{3}$ & 0.0 & 14.7 & 96.5 & 48.6 & 64.0 \\
$\mathbf{4}$ & 0.0 & 22.5 & 105.7 & - & - \\
$\mathbf{5}$ & 0.0 & 16.6 & 96.6 & 48.4 & 66.2 \\
$\mathbf{6}$ & 0.0 & 24.4 & 105.1 & - & -
\end{tabular}

Our results agree with those of Okovytyy et al. [14] now including 3e: 3a $(0.0)>3 \mathbf{b}(14.7)>\mathbf{3 d}(48.6)>\mathbf{3 e}(64.0)>\mathbf{3 c}$ (96.5). For the remaining compounds always is a $(0.0)>\mathbf{b}$ $\left(18 \mathrm{~kJ} \mathrm{~mol}^{-1}\right.$ in average), the other tautomers having considerably higher energies. Always tautomer $\mathbf{b}$ is destabilized by $\mathrm{N}$-methylation (in average, $8.4 \mathrm{~kJ} \mathrm{~mol}^{-1}$ ) probably due to a steric effect; the conjugated tautomer $\mathbf{b}$ tends to be planar and this is indeed the case for $1 H$-derivatives $\mathbf{1 b}, \mathbf{3} \mathbf{b}$ and $\mathbf{4 b}$. The introduction of an $N$-methyl group, derivatives $\mathbf{2 b}, \mathbf{4 b}$ and $\mathbf{6 b}$, fold the seven-membered ring with a concomitant destabilization of these tautomers.

The tautomerism between $\mathbf{a}$ and $\mathbf{b}$ implies the breaking/formation of a $\mathrm{C}-\mathrm{H}$ bond. This is similar to the case of acetylacetone (diketo and ketoenol tautomers) that when both tautomers are present, both can be observed by NMR because the tautomerization barrier is high enough. Therefore, if a $\mathrm{CH}_{2}$ group is observed in ${ }^{1} \mathrm{H}$ or in ${ }^{13} \mathrm{C}$ NMR in the case of 1,5-benzodiazepinones only tautomer a is present in solution.

\section{Chemical shifts and spin-spin coupling constants (SSCC)}

Mannschreck et al. reported the ${ }^{1} \mathrm{H}$ NMR chemical shifts $(\delta$ in ppm) of 3a in $\mathrm{CDCl}_{3}: 2.38\left(\mathrm{CH}_{3}\right), 3.14\left(\mathrm{CH}_{2}\right)$ and $9.99(\mathrm{NH})$ [11]. Benasi et al. reported those of 5a $\left(\delta_{\mathrm{A}}=3.08, \delta_{\mathrm{B}}=4.25\right.$, $\left.J_{\mathrm{AB}}=12.00 \mathrm{~Hz}\right)$ and $\mathbf{6 a}\left(\delta_{\mathrm{A}}=3.02, \delta_{\mathrm{B}}=4.15, J_{\mathrm{AB}}=12.00 \mathrm{~Hz}\right.$; $\mathrm{CH}_{3}, 3.34$ ) in acetone [15]. Those of 5a in DMSO- $d_{6}$ are 3.87 and $4.62 \mathrm{ppm}$ [16]. A paper by Bernardini et al. reports all the ${ }^{13} \mathrm{C}$ NMR chemical shifts and some ${ }^{1} \mathrm{H}-{ }^{13} \mathrm{C}$ coupling constants for compounds 3-6 [17].

We report in Table $2\left({ }^{1} \mathrm{H}\right.$ and ${ }^{19} \mathrm{~F}$ NMR data) and Table $3\left({ }^{13} \mathrm{C}\right.$ and ${ }^{15} \mathrm{~N}$ NMR data) the results we have obtained for compounds $\mathbf{1}$ and $\mathbf{2}$ in different solvents and in the solid state together with the theoretical calculated values.
There are several interesting results concerning the data reported in Table 2. One of them is the $J_{\mathrm{HF}}$ coupling constant present in the $N$-methyl group of compound 2. This coupling constant, of about $4.5 \mathrm{~Hz}$, identifies unambiguously F9, i.e. it is a ${ }^{5} J_{\mathrm{HF} 9}$ because all the calculated values for the coupling constants between the $\mathrm{N}$-methyl protons and the fluorine atoms are very small (about $0.1 \mathrm{~Hz}$ ) except that with F9 (calculated 6.6 Hz). In the literature (Figure 9), there is a related coupling constant present in 2-fluoroacetophenone (8) [18]. Note that this ${ }^{1} \mathrm{H}-{ }^{19} \mathrm{~F}$ coupling can be through-bonds, i.e. a ${ }^{5} \mathrm{~J}$ or throughspace, a common problem involving ${ }^{19} \mathrm{~F}[19,20]$. Starting from the F9 assignment, the $\left({ }^{19} \mathrm{~F}-{ }^{19} \mathrm{~F}\right)$ COSY experiments permitted to establish the correlation F9-F8-F7-F6, in both compounds.

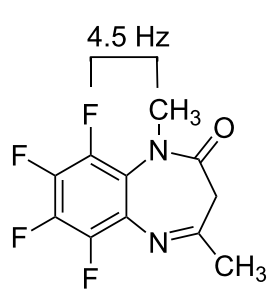

2

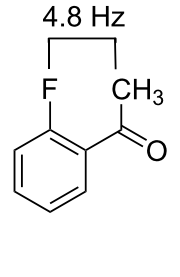

8
Figure 9: ${ }^{1} \mathrm{H}-{ }^{19} \mathrm{~F}$ coupling constant values either through-bond or through-space.

Another interesting coupling is the geminal ${ }^{2} J_{\mathrm{HH}} \approx 12 \mathrm{~Hz}$ of the methylene group in the case of compound 2 . This coupling is well reproduced by the calculations $\approx-10.5 \mathrm{~Hz}$. Next, we compared the experimental and calculated chemical shifts (Table 2). For ${ }^{1} \mathrm{H}$ and ${ }^{19} \mathrm{~F}$ all together, ( $n=44$ values in solution) the correlations are very good $\left(R^{2}=1.000\right)$ but this is due to the fact that these nuclei appear at very different chemical shifts. Considering only the protons and not including the $\mathrm{NH}$ protons $(n=20)$, the regressions are good, for instance, $\delta \mathrm{CDCl}_{3}=-(0.4 \pm 0.1)+(1.26 \pm 0.04) \delta_{\mathrm{Calcd}} R^{2}=0.995$.

The part concerning ${ }^{19} \mathrm{~F}$ chemical shifts is less satisfactory. There are 32 values including those determined in the solid state. Imposing the intercept to be 0 (and considering that the calculations do not reproduce well the chemical shifts of $\mathrm{F} 6$ and $\mathrm{F} 9$, we found $\delta^{19} \mathrm{~F}=(1.005 \pm 0.003) \delta_{\text {Calcd }}-(4.4 \pm 0.7) \mathrm{F} 6+$ $(4.0 \pm 0.7) \mathrm{F} 9+(2.7 \pm 0.7) \mathrm{CPMAS}$. The worse points are $\mathbf{1}$ DMSO- $d_{6}$, F9 exp. -151.1 , fitted $-155.8 ; 2$ toluene- $d_{8}$, F9 exp. -146.3 , fitted -142.9 . The reason of this anomaly concerning the fluorine atoms closer to the nitrogen atoms remains unclear.

In what concerns the FF coupling constants, ${ }^{3} J_{\mathrm{FF}}$ and ${ }^{5} J_{\mathrm{FF}}$ agree with the calculated values; the average values being: experimental $|21.4|\left({ }^{3} J_{\mathrm{F}}\right)$ and $|9.1|\left({ }^{3} J_{\mathrm{F} 9}\right)$ and calculated $-22.0\left({ }^{3} J_{\mathrm{F}}\right)$ and $11.1 \mathrm{~Hz}\left({ }^{3} J_{\mathrm{F} 9}\right)$. 


\begin{tabular}{|c|c|c|c|c|c|c|c|c|}
\hline Comp. & Conditions & $\mathrm{CH}_{3}$ & $\mathrm{CH}_{2}$ & NR & F6 & $\mathrm{F} 7$ & F8 & F9 \\
\hline 1 & $\mathrm{CDCl}_{3}$ & 2.46 & $\begin{array}{l}3.24 \\
\Delta \delta=0.00\end{array}$ & $\begin{array}{l}\mathrm{R}=\mathrm{H} \\
8.08\end{array}$ & $\begin{array}{l}-147.8 \\
3 J_{F 7}=21.6 \\
{ }^{5} J_{F 9}=9.6\end{array}$ & $\begin{array}{l}-161.9 \\
{ }^{3} J_{\mathrm{F} 8}=21.6\end{array}$ & $\begin{array}{l}-159.7 \\
{ }^{3} J_{F 9}=21.6\end{array}$ & -154.5 \\
\hline 1 & toluene- $d_{8}$ & 1.83 & $\begin{array}{l}2.39 \\
\Delta \delta=0.00\end{array}$ & $\begin{array}{l}\mathrm{R}=\mathrm{H} \\
7.80\end{array}$ & $\begin{array}{l}-148.5 \\
3 J_{F 7}=21.7 \\
5 J_{F 9}=9.6\end{array}$ & $\begin{array}{l}-163.8 \\
3 J_{F 8}=21.7\end{array}$ & $\begin{array}{l}-161.7 \\
3^{3} J_{F 9}=21.7\end{array}$ & -154.8 \\
\hline 1 & DMSO- $d_{6}$ & 2.32 & $\begin{array}{l}3.24 \\
\Delta \delta=0.00\end{array}$ & $\begin{array}{l}R=H \\
10.66\end{array}$ & $\begin{array}{l}-149.8 \\
3 J_{F 7}=22.7 \\
{ }^{5} J_{F 9}=7.5\end{array}$ & $\begin{array}{l}-164.6 \\
{ }^{3} J_{\mathrm{F} 8}=22.7\end{array}$ & $\begin{array}{l}-162.5 \\
{ }^{3} J_{F 9}=22.7\end{array}$ & -151.1 \\
\hline 1 & solid state $^{a}$ & - & - & - & -144.9 & -161.5 & -159.0 & -150.6 \\
\hline 1 & calculated & 2.31 & $\begin{array}{l}2.49(\mathrm{ax}) \\
3.23(\mathrm{eq}) \\
\Delta \delta=0.74 \\
J_{\mathrm{ae}}=-10.6^{\mathrm{b}}\end{array}$ & $\begin{array}{l}\mathrm{R}=\mathrm{H} \\
6.71\end{array}$ & $\begin{array}{l}-142.8 \\
{ }^{3} J_{F 7}=-22.0 \\
{ }^{4} J_{F 8}=-1.5 \\
{ }^{5} J_{F 9}=+11.6\end{array}$ & $\begin{array}{l}-163.0 \\
3^{3} J_{F 8}=-21.9 \\
{ }^{4} J_{F 9}=-6.0\end{array}$ & $\begin{array}{l}-160.0 \\
{ }^{3} J_{F 9}=-22.0\end{array}$ & $\begin{array}{l}-159.0 \\
{ }^{4} J_{F 7}=-6.0\end{array}$ \\
\hline 2 & $\mathrm{CDCl}_{3}$ & 2.43 & $\begin{array}{l}2.93(\mathrm{ax}) \\
3.53(\mathrm{eq}) \\
\Delta \delta=0.60 \\
J_{\mathrm{ae}}=11.7\end{array}$ & $\begin{array}{l}R=\operatorname{Me} 3.30(d) \\
5 J_{F 9}=4.2\end{array}$ & $\begin{array}{l}-148.5 \\
{ }^{3} J_{F 7}=20.7 \\
{ }^{5} J_{F 9}=8.8\end{array}$ & $\begin{array}{l}-159.7 \\
{ }^{3} J_{\mathrm{F} 8}=20.7\end{array}$ & $\begin{array}{l}-159.8 \\
{ }^{3} J_{F 9}=20.7\end{array}$ & $-145.2^{b}$ \\
\hline 2 & toluene- $d_{8}$ & 1.85 & $\begin{array}{l}2.03(\mathrm{ax}) \\
2.86(\mathrm{eq}) \\
\Delta \delta=0.83 \\
J_{\mathrm{ae}}=11.6\end{array}$ & $\begin{array}{l}\mathrm{R}=\operatorname{Me~} 2.88(\mathrm{~d}) \\
{ }^{5} J_{F 9}=4.4\end{array}$ & $\begin{array}{l}-148.7 \\
{ }^{3} J_{F 7}=21.4 \\
{ }^{5} J_{F 9}=8.4\end{array}$ & $\begin{array}{l}-161.3 \\
3 J_{F 8}=21.4\end{array}$ & $\begin{array}{l}-161.6 \\
{ }^{3} J_{F 9}=21.4\end{array}$ & $\begin{array}{l}-146.3 \\
4 J_{F 7}=8.4 \\
{ }^{5} J_{\mathrm{CH} 3}=4.4\end{array}$ \\
\hline 2 & DMSO- $d_{6}$ & 2.31 & $\begin{array}{l}3.19(\mathrm{ax}) \\
3.45(\mathrm{eq}) \\
\Delta \delta=0.27 \\
J_{\mathrm{ae}}=12.1\end{array}$ & $\begin{array}{l}\mathrm{R}=\operatorname{Me} 3.18(\mathrm{~d}) \\
{ }^{5} J_{\mathrm{F} 9}=4.6\end{array}$ & $-150.0^{C}$ & $-162.1^{c}$ & $-162.1^{c}$ & $-144.7^{c}$ \\
\hline 2 & solid state ${ }^{a}$ & - & - & - & -146.0 & -156.8 & -160.9 & -142.1 \\
\hline 2 & calculated & 2.27 & $\begin{array}{l}2.47(\mathrm{ax}) \\
3.20(\mathrm{eq}) \\
\Delta \delta=0.73 \\
J_{\mathrm{ae}}=-10.3\end{array}$ & $\begin{array}{l}\mathrm{R}=\operatorname{Me} 3.13(\mathrm{~d}) \\
{ }^{5} J_{\mathrm{F} 9}=6.6\end{array}$ & $\begin{array}{l}-144.3 \\
{ }^{3} J_{F 7}=-22.2 \\
{ }^{4} J_{F 8}=-2.8 \\
5 J_{F 9}=+10.6\end{array}$ & $\begin{array}{l}-160.4 \\
3^{3} J_{F 8}=-22.1 \\
{ }^{4} J_{F 9}=-3.3\end{array}$ & $\begin{array}{l}-160.7 \\
{ }^{3} J_{F}=-21.6\end{array}$ & $\begin{array}{l}-146.1 \\
{ }^{4} J_{F 7}=-3.3\end{array}$ \\
\hline
\end{tabular}

a Obtained using the hpdec.av sequence; ${ }^{\mathrm{b}}$ This coupling constant agrees with the experimental one found at $193 \mathrm{~K}$ in toluene- $d_{8}$ (see Barriers section); ${ }^{\mathrm{C} C o m p l e x ~ m u l t i p l e t . ~}$

Table 3 reports the ${ }^{13} \mathrm{C}$ and ${ }^{15} \mathrm{~N}$ NMR data; here the situation is more difficult because the ${ }^{13} \mathrm{C}$ NMR signals of the benzene ring carbons are coupled with all the fluorine atoms giving rise to multiplets, which have been analyzed using the Mnova 8.1.0 NMR software [21] for spin simulation, and when needed by irradiation of the ${ }^{1} \mathrm{H}$ nuclei to simplify the spectra. In the gs-HMBC $\left({ }^{1} \mathrm{H}-{ }^{13} \mathrm{C}\right)$ spectra, a correlation between the $\mathrm{C} 4-\mathrm{CH}_{3}$ protons and $\mathrm{C} 4$ permitted to assign to the latter the chemical shifts at $168.7 \mathrm{ppm}$ for $\mathbf{1}$ and $\mathbf{1 7 0 . 9}$ for $\mathbf{2}$, in accordance with the calculated values. However, the ${ }^{13} \mathrm{C}$ CPMAS signals corresponding to carbon atoms $\mathrm{C} 6$ to $\mathrm{C} 9$ could not be properly analyzed, and only the centers of the multiplets are given (138.1 and $138.6 \mathrm{ppm}$ for $\mathbf{1}$ and $\mathbf{2}$, respectively). Some couplings involving the fluorine atoms are not well reproduced by the calculations, this is particularly apparent for the ${ }^{1} J_{\mathrm{CF}}$, that are overestimated, in absolute value, by about $68 \mathrm{~Hz}$. The overestimation and difficulty to calculate coupling constants involving ${ }^{19} \mathrm{~F}$ has been reported several times $[20,22,23]$.
Concerning the ${ }^{15} \mathrm{~N}$ experimental spectra all nitrogen atoms appear as singlets in solution as well as in the solid state, only small coupling constants with the fluorine substituents have been theoretically calculated so most probably the width of the experimental signals mask them.

In Table $\mathrm{S} 1$ in Supporting Information File 1 the experimental (from references [11,15-17]) and calculated ${ }^{1} \mathrm{H},{ }^{13} \mathrm{C}$ and ${ }^{15} \mathrm{~N}$ NMR chemical shifts ( $\left.\delta, \mathrm{ppm}\right)$ of compounds $\mathbf{3 a}$ to $\mathbf{6 a}$ are reported. The agreement between experimental and calculated values is either good or excellent.

\section{Barriers (all in $\mathrm{kJ} \mathrm{mol}^{-1}$ )}

The experimental inversion barriers of 3a, 5a (twice) and $6 \mathbf{a}$ have been determined and are given in Table 4. We have calculated those of 1a and 2a. The barriers for an $\mathrm{AB}$ system that become an $\mathrm{A}_{2}$ one depend on three values: i) the coalescence temperature $T_{\mathrm{C}}$; ii) the difference in $\mathrm{Hz}$ of the protons of the $\mathrm{AB}$ 
Table 3: ${ }^{13} \mathrm{C}$ and ${ }^{15} \mathrm{~N}$ NMR chemical shifts $(\delta, \mathrm{ppm})$ and some coupling constants $(\mathrm{Hz})$ of compounds 1 and 2 in solution and in the solid state together with the calculated values (ppm and $\mathrm{Hz}$ ).

\begin{tabular}{|c|c|c|c|c|c|c|c|c|}
\hline Comp. & Conditions & $\mathrm{C} 2$ & C3 & $\mathrm{C} 4$ & $4-\mathrm{CH}_{3}$ & $\mathrm{~N}-\mathrm{CH}_{3}$ & C5a & $\mathrm{C9a}$ \\
\hline 1 & DMSO-d 6 & 165.3 & 44.6 & 168.7 & 27.6 & - & $\begin{array}{l}126.6^{2} \mathrm{~J}= \\
9.9\end{array}$ & $\begin{array}{l}117.1 \\
2 J=13.1\end{array}$ \\
\hline 1 & CPMAS & 167.1 & 44.4 & 169.2 & 25.6 & - & 125.2 & 116.5 \\
\hline 1 & Calcd & 161.4 & 44.5 & 165.8 & 27.9 & - & $\begin{array}{l}126.5 \\
2 J_{F 6}=4.0\end{array}$ & $\begin{array}{l}116.2 \\
2 J_{F 9}=3.4\end{array}$ \\
\hline 2 & DMSO-d 6 & 165.0 & 43.7 & 170.9 & 27.4 & $\begin{array}{l}35.8 \\
{ }^{4} J_{F 9}=8.7\end{array}$ & $\begin{array}{l}128.4 \\
2 J=11.2\end{array}$ & $\begin{array}{l}121.2 \\
2 J=8.9\end{array}$ \\
\hline 2 & CPMAS & 165.8 & 42.6 & 173.3 & 27.3 & 36.2 & 128.7 & 121.5 \\
\hline \multirow[t]{2}{*}{2} & Calcd & 162.3 & 44.1 & 168.9 & 27.4 & $\begin{array}{l}36.9 \\
{ }^{4} J_{F 9}=8.5\end{array}$ & $\begin{array}{l}129.8 \\
2 J_{F 6}=2.7\end{array}$ & $\begin{array}{l}122.2 \\
2 J_{F 9}=2.1\end{array}$ \\
\hline & & $\mathrm{C} 6$ & $\mathrm{C} 7$ & $\mathrm{C} 8$ & $\mathrm{C9}$ & N1 & N5 & \\
\hline 1 & DMSO- $d_{6}$ & $\begin{array}{l}140.9 \\
1 J=246.0 \\
2 J=10.5 \\
3 J=3.7\end{array}$ & $\begin{array}{l}136.3 \\
1 J=245.3 \\
2 J \approx 13.5 \\
2 J \approx 11.6 \\
3 J=3.8\end{array}$ & $\begin{array}{l}137.3 \\
1 J=246.0 \\
2 J \approx 14.0 \\
2 J \approx 13.2 \\
3 J=4.4\end{array}$ & $\begin{array}{l}138.2 \\
1 J=245.3 \\
2 J=11.8 \\
3 J=3.8\end{array}$ & -254.3 & -86.9 & \\
\hline 1 & CPMAS & $138.1^{a}$ & $138.1^{a}$ & $138.1^{a}$ & $138.1^{a}$ & -249.6 & -85.0 & \\
\hline 1 & Calcd & $\begin{array}{l}145.2 \\
1 J=-316.6\end{array}$ & $\begin{array}{l}139.8 \\
1 \mathrm{~J}=-314.4\end{array}$ & $\begin{array}{l}140.7 \\
1 \mathrm{~J}=-316.7\end{array}$ & $\begin{array}{l}139.1 \\
1 J=-303.3\end{array}$ & $\begin{array}{l}-256.7 \\
{ }^{3} J_{N 1 F 9}=-1.9\end{array}$ & $\begin{array}{l}-82.0 \\
{ }^{4} J_{N 5 F 7}=1.5 \\
{ }^{3} J_{N 5 F 6}=5.2\end{array}$ & \\
\hline 2 & DMSO- $d_{6}$ & $\begin{array}{l}140.6 \\
1 J=251.4 \\
2 J=12.1 \\
3 J=5.0\end{array}$ & $\begin{array}{l}137.3 \\
1 J=248.3 \\
2 J \approx 16.2 \\
2 J \approx 15.4 \\
3 J=4.8\end{array}$ & 137.3 & $\begin{array}{l}140.2 \\
1 J=241.8 \\
2 J=14.6 \\
3 J=4.9\end{array}$ & -264.3 & -90.5 & \\
\hline 2 & CPMAS & $138.6^{a}$ & $138.6^{a}$ & $138.6^{a}$ & $138.6^{a}$ & -259.2 & -90.2 & \\
\hline 2 & Calcd & $\begin{array}{l}143.8 \\
{ }^{1} \mathrm{~J}=-316.1\end{array}$ & $\begin{array}{l}140.7 \\
1 J=-315.5\end{array}$ & $\begin{array}{l}140.3 \\
1 J=-315.3\end{array}$ & $\begin{array}{l}142.8 \\
1 \mathrm{~J}=-310.3\end{array}$ & $\begin{array}{l}-256.2 \\
{ }^{3} J_{N 1 F 9}=-2.1\end{array}$ & $\begin{array}{l}-85.0 \\
4 J_{N 5 F 7}=1.4 \\
{ }^{3} J_{N 5 F 6}=5.2\end{array}$ & \\
\hline
\end{tabular}

aVery complex multiplet.

Table 4: Experimental al calculated inversion barriers $\left(\mathrm{kJ} \mathrm{mol}^{-1}\right)$

\begin{tabular}{|c|c|c|c|c|c|c|}
\hline & $1 a$ & $2 a$ & $3 a$ & $4 a$ & $5 a$ & $6 a$ \\
\hline$\Delta G^{\ddagger}$ exp & $\begin{array}{l}\text { toluene- } d_{8} \\
T_{\mathrm{C}}=230 \mathrm{~K} \\
\Delta \mathrm{v}_{\mathrm{AB}}=450.0 \mathrm{~Hz} \\
J_{\mathrm{AB}}=10.9 \mathrm{~Hz} \\
42.6\end{array}$ & $\begin{array}{l}\text { DMSO- } d_{6} \\
T_{\mathrm{C}}=373 \mathrm{~K} \\
\Delta \mathrm{v}_{\mathrm{AB}}=103.5 \mathrm{~Hz} \\
J_{\mathrm{AB}}=12.1 \mathrm{~Hz} \\
75.0 \\
\text { toluene- } d_{8} \\
T_{\mathrm{C}}=363 \mathrm{~K} \\
\Delta \mathrm{v}_{\mathrm{AB}}=303.1 \mathrm{~Hz} \\
J_{\mathrm{AB}}=11.6 \mathrm{~Hz} \\
69.8\end{array}$ & $\begin{array}{l}\text { pyridine- } d_{5} / \mathrm{CDCl}_{3} \\
39.8[11]\end{array}$ & - & $\begin{array}{l}\text { acetone- } d_{6} \\
41.8[15] \\
52.7[16]\end{array}$ & $\begin{array}{l}\text { acetone- } d_{6} \\
65.3[15]\end{array}$ \\
\hline$\Delta G^{\ddagger}$ calcd. & 36.7 & 81.7 & 42.4 & 61.9 & 38.2 & 63.8 \\
\hline
\end{tabular}

system $\left(\Delta v_{\mathrm{AB}}\right)$, and iii) the geminal coupling constant, $J_{\mathrm{AB}}$ (or $\left.J_{\mathrm{ae}}\right)$. The inversion rate at the coalescence temperature for an $\mathrm{AB}$ system is given by $k_{\mathrm{C}}=\pi / \sqrt{2} \cdot \sqrt{ } \Delta v^{2}+6 J_{\mathrm{AB}}^{2}$ [11] and the barrier by the modified Eyring equation [24-26], $\Delta G^{\star}=$ $19.12 \cdot T_{\mathrm{C}}\left(10.32+\log T_{\mathrm{C}} / k_{\mathrm{C}}\right)[18-20]$. From the values in
Table 4 we have determined the corresponding experimental inversion barriers.

The agreement between experimental and calculated values is satisfactory: using for $\mathbf{2 a}$ the $75.0 \mathrm{~kJ} \mathrm{~mol}^{-1}$ and for $\mathbf{5 a}$ the 
$41.8 \mathrm{~kJ} \mathrm{~mol}^{-1}$ values we obtained by linear regression (no intercept) $\Delta G_{\text {exp. }}^{\ddagger}=(0.99 \pm 0.04) \Delta G_{\text {calcd }}^{\ddagger}, n=5, R^{2}=0.993$. This equation predicts for $4 \mathrm{a} 61.0 \mathrm{~kJ} \mathrm{~mol}^{-1}$. Note the increase between toluene and DMSO that corresponds to the raise of inversion barriers with that of the solvent polarity; a similar behavior has been reported for diazepam (7-chloro-1,3-dihydro1-methyl-5-phenyl-2H-1,4-benzodiazepin-2-one) [27].

When using calculated values it is possible to analyze the main effects on the barriers that in the present case are three: i) $\mathrm{N}$-methylation; ii) 6,7,8,9-tetrafluorination; iii) the substituent at position $4\left(\mathrm{CH}_{3}\right.$ or $\left.\mathrm{C}_{6} \mathrm{H}_{5}\right)$. This last effect is negligible, the other two interact, then a product term ( $\mathrm{i} \cdot \mathrm{ii})$ is necessary to model the behavior. The regression corresponds to the following equation (all values in $\mathrm{kJ} \mathrm{mol}^{-1}$ ):

Calculated barrier $=(40.3 \pm 1.6)+(22.6 \pm 2.3) N \mathrm{Me}-(3.6 \pm$ 2.8) $\mathrm{C}_{6} \mathrm{~F}_{4}+(22.5 \pm 4.0) N \mathrm{Me}^{*} \mathrm{C}_{6} \mathrm{~F}_{4}, n=6, R^{2}=0.993$

The average barrier is $40.3 \mathrm{~kJ} \mathrm{~mol}^{-1}$. $N$-Methylation increases the barrier $22.6 \mathrm{~kJ} \mathrm{~mol}^{-1}$ in average; the introduction of four $\mathrm{F}$ atoms produces a small effect of $3.6 \mathrm{~kJ} \mathrm{~mol}^{-1}$ but when there is simultaneously an $\mathrm{N}$-methyl group and four F atoms (compound $\mathbf{2 a}$ ), the increase of the barrier is considerable $\left(22.5 \mathrm{~kJ} \mathrm{~mol}^{-1}\right)$. An examination of the TS for $\mathbf{2 a}$ shows that the protons of the $\mathrm{N}$-methyl group are very close to F9 (Figure 10).

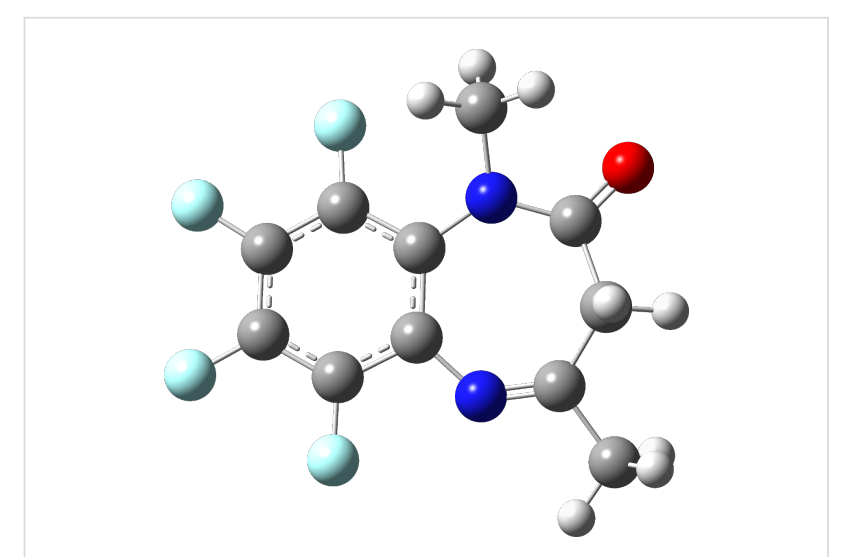

Figure 10: The optimized geometry of the TS of $2 \mathrm{a}$ inversion.

\section{Conclusion}

A clearer picture of the behavior of 1,5-benzodiazepinones emerges from the present paper. Concerning tautomerism, our results confirm previous studies while extending them to the 6,7,8,9-tetrafluoro derivatives. The folding of the structures in the solid-state is general, the $N$-methyl group having a marked effect. An exhaustive NMR study of the tetrafluoro derivatives, together with literature data on four other non-fluorinated 1,5benzodiazepinones, lead to values of the chemical shifts that compare well with GIAO calculated ones with the exception of F6 and F9. Finally, the inversion barrier of the seven-membered ring of the new compounds has been determined and compared with theoretically calculated values, illustrating the considerable effect of the $N$-methylation particularly when there is a fluorine atom on $\mathrm{C} 9$.

\section{Experimental}

General Information. All chemicals cited in the synthetic procedures are commercial compounds. Melting points were determined by DSC with a SEIKO DSC220C connected to a model SSC5200H disk station. Thermograms (sample size $0.004 \mathrm{~g}$ ) were recorded with a scan rate of $5.0^{\circ} \mathrm{C}$. Column chromatography was performed on silica gel (Merck 60, 70-230 mesh) and elemental analyses using a Perkin-Elmer 240 apparatus.

6,7,8,9-Tetrafluoro-4-methyl-1,3-dihydro-2H-1,5-benzodiazepin-2-one (1). 1,2-Diamino-3,4,5,6-tetrafluorobenzene $(0.50 \mathrm{~g}, 2.78 \mathrm{mmol})$ and ethyl acetylacetate $(0.36 \mathrm{~mL}$, $2.85 \mathrm{mmol})$ were heated at $120^{\circ} \mathrm{C}$ in anhydrous xylene $(5 \mathrm{~mL})$ for 6 hours. The mixture was cooled and then a solid precipitated. This residue was washed with diethyl ether to give compound 1 (0.43 g, 63\%); white solid; $\mathrm{mp} 155.2{ }^{\circ} \mathrm{C}$. Anal. calcd for $\mathrm{C}_{10} \mathrm{H}_{6} \mathrm{~F}_{4} \mathrm{~N}_{2} \mathrm{O}$ : C, 48.79; H, 2.46; N, 11.38; found: C, 48.04; $\mathrm{H}, 2.60$; N, 11.41 .

6,7,8,9-Tetrafluoro-1,4-dimethyl-1,3-dihydro-2H-1,5-benzodiazepin-2-one (2). A solution of $1(0.40 \mathrm{~g}, 1.62 \mathrm{mmol})$ in DMF ( $2 \mathrm{~mL})$ was heated at $110{ }^{\circ} \mathrm{C}$ in the presence of iodomethane $(0.11 \mathrm{~mL}, 1.79 \mathrm{mmol}), \mathrm{K}_{2} \mathrm{CO}_{3}(0.27 \mathrm{~g}$, $1.95 \mathrm{mmol}$ ) and a catalytic quantity of KI for $90 \mathrm{~min}$. The mixture was cooled, treated with cold water and extracted with ethyl acetate. The ethyl acetate was evaporated and the crude was purified by column chromatography (hexane/ethyl acetate 7:3) to afford compound 2 ( $0.34 \mathrm{~g}, 80 \%$ ); pale yellow solid; mp 132.2 ${ }^{\circ} \mathrm{C}$. Anal. calcd for $\mathrm{C}_{11} \mathrm{H}_{8} \mathrm{~F}_{4} \mathrm{~N}_{2} \mathrm{O}: \mathrm{C}, 50.78 ; \mathrm{H}, 3.10 ; \mathrm{N}$, 10.77; found: $\mathrm{C}, 50.91 ; \mathrm{H}, 3.15 ; \mathrm{N}, 10.76$.

X-ray data collection and structure refinement. Data collection for all compounds was carried out at room temperature on a Bruker Smart CCD diffractometer using graphitemonochromated Mo K $\alpha$ radiation $(\lambda=0.71073 \AA)$ operating at $50 \mathrm{kV}$ and $30 \mathrm{~mA}$ for $\mathbf{1}$ and $\mathbf{2}$. In all cases, data were collected over a hemisphere of the reciprocal space by combination of three exposure sets. Each exposure was of $20 \mathrm{~s}$ covered 0.3 in $\omega$. The cell parameter were determined and refined by a leastsquares fit of all reflections. The first 100 frames were recollected at the end of the data collection to monitor crystal decay, and no appreciable decay was observed. A summary of the fundamental crystal and refinement data is given in Table 5 . 
The structures were solved by direct methods and refined by full-matrix least-square procedures on $\mathrm{F}^{2}$ (SHELXL-97) [28]. All non-hydrogen atoms were refined anisotropically.

The hydrogen atoms were included in their calculated positions and refined riding on the respective carbon atoms with the exception of hydrogen $\mathrm{H} 1$ bonded to $\mathrm{N} 1$ for 1 that was located in a Fourier synthesis and refined riding on the respective bonded atom.

Further crystallographic details for the structure reported in this paper may be obtained from The Cambridge Crystallographic Data Center, on quoting the depository numbers CCDC 946878 and 946879. Copies of the data can be obtained free of charge on application to The Director, CCDC, 12 Union Road, Cambridge DB2 1EZ, UK (Fax: int. code +(1223)336-033; email: deposit@ccdc.cam.ac.uk).

Theoretical calculations. The geometry of the molecules has been fully optimized with the hybrid HF/DFT B3LYP [29-31] computational method and the 6-31G(d) basis set [32]. Frequency calculations have been carried out at the same computational level to verify that the structures obtained correspond to energetic minima. A further optimization has been carried out at the B3LYP/6-311++G(d,p) level $[33,34]$. These geometries have been used for the calculations of the absolute chemical shieldings with the GIAO method $[35,36]$ and the B3LYP/6-311++G(d,p) computational level. All the calculations have been carried out with the Gaussian-09 package [37].

The literature equations shown in Figure 11 have been used to transform absolute shieldings into chemical shifts.

\section{Experimental NMR}

Solution spectra were recorded on a Bruker DRX 400 (9.4 Tesla, $400.13 \mathrm{MHz}$ for ${ }^{1} \mathrm{H}, 100.62 \mathrm{MHz}$ for ${ }^{13} \mathrm{C}$, $40.56 \mathrm{MHz}$ for ${ }^{15} \mathrm{~N}$ and $379.50 \mathrm{MHz}$ for ${ }^{19} \mathrm{~F}$ ) using a $5 \mathrm{~mm}$ QNP direct-detection probehead equipped with a z-gradient coil, at $300 \mathrm{~K}$. Chemical shifts ( $\delta$ in ppm) are given from internal solvent, DMSO- $d_{6} 2.49$ for ${ }^{1} \mathrm{H}$ and 39.5 for ${ }^{13} \mathrm{C} ; \mathrm{CDCl}_{3}$ 7.26 for ${ }^{1} \mathrm{H}$ and toluene- $d_{8} 2.09$ for ${ }^{1} \mathrm{H}$, and for ${ }^{15} \mathrm{~N}$ and ${ }^{19} \mathrm{~F}$ NMR, nitromethane (0.00) and one drop of $\mathrm{CFCl}_{3}$ in $\mathrm{CDCl}_{3}$ $(0.00)$ were used as external references.

Typical parameters for ${ }^{1} \mathrm{H}$ NMR spectra were spectral width of $4800 \mathrm{~Hz}$ and pulse width of $10.25 \mu$ s at an attenuation level of $-3.0 \mathrm{~dB}$. Typical parameters for ${ }^{13} \mathrm{C} \mathrm{NMR}$ spectra were spectral width of $21 \mathrm{kHz}$, pulse width of $8.75 \mu \mathrm{s}$ at an attenuation

\begin{tabular}{|c|c|c|}
\hline Crystal Data & 1 & 2 \\
\hline Empirical formula & $\mathrm{C}_{10} \mathrm{H}_{6} \mathrm{~F}_{4} \mathrm{~N}_{2} \mathrm{O}_{1}$ & $\mathrm{C}_{11} \mathrm{H}_{8} \mathrm{~F}_{4} \mathrm{~N}_{2} \mathrm{O}_{1}$ \\
\hline Formula wt & 246.17 & 260.19 \\
\hline Crystal system. Space group & Monoclinic $P 2_{1} / c$ & Triclinic $P-1$ \\
\hline$a / \AA$ & $5.2821(5)$ & $7.224(4)$ \\
\hline$b / \AA ̊$ & $18.255(1)$ & $8.064(4)$ \\
\hline$c / \AA$ & $10.2102(9)$ & $10.478(5)$ \\
\hline$\alpha / /^{\circ}$ & & $77.136(9)$ \\
\hline$\beta /^{\circ}$ & $100.93(1)$ & $76.311(9)$ \\
\hline $\mathrm{Y}^{\circ}$ & & $68.510(8)$ \\
\hline$V I \AA^{3}$ & $966.6(1)$ & $545.5(5)$ \\
\hline$Z$ & 4 & 2 \\
\hline$D_{\mathrm{c}} / \mathrm{g} / \mathrm{cm}^{3}$ & 1.692 & 1.584 \\
\hline$\mu(\mathrm{Mo} \mathrm{K \alpha}) / \mathrm{mm}^{-1}$ & 0.164 & 0.150 \\
\hline$F(000)$ & 496 & 264 \\
\hline$\theta$ range $/^{\circ}$ & 2.23 to 25.01 & 2.02 to 25.00 \\
\hline Index ranges & $-6,-18,-8$ to $6,21,12$ & $-8,-9,-12$ to $7,9,12$ \\
\hline Reflections collected & 4110 & 4184 \\
\hline Unique reflections [Rint] & $1709[$ Rint $=0.0233]$ & $1869[R$ (int) $=0.0350]$ \\
\hline Completeness to theta & $100 \%$ & $97.0 \%$ \\
\hline Data/restraints/params & $1709 / 0 / 155$ & $1869 / 0 / 163$ \\
\hline Goodness-of-fit on $\mathrm{F}^{2}$ & 1.006 & 0.999 \\
\hline$R 1$ (reflns obsd) $[I>2 \sigma(I)]^{a}$ & $0.0386(1267)$ & $0.0443(1306)$ \\
\hline$w R 2$ (all data) $\mathrm{b}$ & 0.0935 & 0.1539 \\
\hline
\end{tabular}

${ }^{a} R 1=\Sigma|| F_{0}|-| F_{c}|| \Sigma\left|F_{o}\right| \cdot{ }^{b} w 2=\left\{\Sigma\left[w\left(F_{o}^{2}-F_{c}^{2}\right)^{2}\right] / \Sigma\left[w\left(F_{o}^{2}\right)^{2}\right]\right\}$. 


$$
\begin{array}{ll}
\delta{ }^{1} \mathrm{H}=31.0-0.97 \cdot \sigma^{1} \mathrm{H} & \text { equation } 1 \text { (reference TMS, } 0.00 \mathrm{ppm} \text { ) [38] } \\
\delta^{13} \mathrm{C}=175.7-0.963 \cdot \sigma^{13} \mathrm{C} & \text { equation } 2 \text { (reference TMS, 0.00 ppm) [39] } \\
\delta^{15} \mathrm{~N}=-152.0-0.946 \cdot \sigma^{15} \mathrm{~N} & \text { equation } 3 \text { (external reference neat } \mathrm{MeNO}_{2}, 0.00 \mathrm{ppm} \text { ) [39] }
\end{array}
$$

level of $-3 \mathrm{~dB}$ and relaxation delay of $2 \mathrm{~s}$, WALTZ-16 used for broadband proton decoupling; the FIDS were multiplied by an exponential weighting $(\mathrm{lb}=1 \mathrm{~Hz})$ before Fourier transformation. Typical parameters for ${ }^{19} \mathrm{~F}$ NMR spectra were spectral width of $55 \mathrm{kHz}$, pulse width of $13.75 \mu$ at an attenuation level of $-6 \mathrm{~dB}$ and relaxation delay of $1 \mathrm{~s}$. WALTZ-16 was used for broadband proton decoupling ${ }^{19} \mathrm{~F}\left\{{ }^{1} \mathrm{H}\right\}$, the FIDS were multiplied by an exponential weighting $(\mathrm{lb}=1 \mathrm{~Hz})$ before Fourier transformation. Homonuclear ${ }^{19} \mathrm{~F}-{ }^{19} \mathrm{~F}$ experiment does not require any modification of the standard gs-COSY pulse sequences; selected parameters for ${ }^{19} \mathrm{~F}$ COSY spectra were: spectral width of $55 \mathrm{KHz}, \mathrm{TD} 1=512$ for $F_{1}$ domain, spectral width of $55 \mathrm{KHz}, \mathrm{TD} 1=1024$ for $F_{2}$ domain, number of scans 4 , dummy scans DS $=2$ and relaxation delay of $1 \mathrm{~s}$.

Inverse proton detected heteronuclear shift correlation spectra, $\left({ }^{1} \mathrm{H}-{ }^{13} \mathrm{C}\right)$ gs-HMBC, were acquired and processed using standard Bruker NMR software and in nonphase-sensitive mode. Gradient selection was achieved through a $5 \%$ sine truncated shaped pulse gradient of $1 \mathrm{~ms}$.

Inverse proton-detected heteronuclear shift correlation spectra, $\left({ }^{1} \mathrm{H}-{ }^{15} \mathrm{~N}\right)$ gs-HMQC and $\left({ }^{1} \mathrm{H}-{ }^{15} \mathrm{~N}\right)$ gs-HMBC, were acquired and processed using standard Bruker NMR software and in nonphase-sensitive mode. Gradient selection was achieved through a $5 \%$ sine truncated shaped pulse gradient of $1 \mathrm{~ms}$. Selected parameters for $\left({ }^{1} \mathrm{H}-{ }^{15} \mathrm{~N}\right)$ gs-HMQC and $\left({ }^{1} \mathrm{H}-{ }^{15} \mathrm{~N}\right)$ gs-HMBC spectra were spectral width of $3500 \mathrm{~Hz}$ for ${ }^{1} \mathrm{H}$ and $12.5 \mathrm{kHz}$ for ${ }^{15} \mathrm{~N}, 1024 \times 256$ data set, number of scans 4 , relaxation delay of $1 \mathrm{~s}, 37-60 \mathrm{~ms}$ delay for evolution of the ${ }^{15} \mathrm{~N}-{ }^{1} \mathrm{H}$ long-range coupling. The FIDs were processed using zero filling in the $F_{1}$ domain and a sine-bell window function in both dimensions was applied prior to Fourier transformation.

Variable temperature was performed using a Bruker BVT3000 temperature unit to control the temperature of the cooling gas stream and an exchanger to achieve low temperatures. To avoid problems at low temperatures caused by air moisture, pure nitrogen was used as bearing, driving and cooling gas.
Solid state ${ }^{13} \mathrm{C}(100.73 \mathrm{MHz})$ and ${ }^{15} \mathrm{~N}(40.60 \mathrm{MHz})$ CPMAS NMR spectra have been obtained on a Bruker WB 400 spectrometer at $300 \mathrm{~K}$ using a $4 \mathrm{~mm}$ DVT probehead. Samples were carefully packed in $4 \mathrm{~mm}$ diameter cylindrical zirconia rotors with Kel-F end-caps. Operating conditions involved $2.9 \mu \mathrm{s} 90^{\circ}$ ${ }^{1} \mathrm{H}$ pulses and decoupling field strength of $86.2 \mathrm{kHz}$ by TPPM sequence. ${ }^{13} \mathrm{C}$ NMR spectra were originally referenced to a glycine sample and then the chemical shifts were recalculated to the $\mathrm{Me}_{4} \mathrm{Si}$ (for the carbonyl atom $\delta($ glycine $)=176.1 \mathrm{ppm}$ ) and ${ }^{15} \mathrm{~N}$ NMR spectra to ${ }^{15} \mathrm{NH}_{4} \mathrm{Cl}$ and then converted to nitromethane scale using the relationship: $\delta{ }^{15} \mathrm{~N}$ (nitromethane) $=\delta{ }^{15} \mathrm{~N}$ (ammonium chloride $)-338.1 \mathrm{ppm}$.

The typical acquisition parameters for ${ }^{13} \mathrm{C}$ CPMAS were: spectral width, $40 \mathrm{kHz}$; recycle delay, $5 \mathrm{~s}$; acquisition time, $30 \mathrm{~ms}$; contact time, $2 \mathrm{~ms}$; and spin rate, $12 \mathrm{kHz}$. In order to distinguish protonated and unprotonated carbon atoms, the NQS (non-quaternary suppression) experiment by conventional cross-polarization was recorded; before the acquisition the decoupler is switched off for a very short time of $25 \mu$ s [40-42]. And for ${ }^{15} \mathrm{~N}$ CPMAS were: spectral width, $40 \mathrm{kHz}$; recycle delay, $5 \mathrm{~s}$; acquisition time, $35 \mathrm{~ms}$; contact time, $6 \mathrm{~ms}$; and spin rate, $6 \mathrm{kHz}$.

Solid-state ${ }^{19} \mathrm{~F}$ (376.94 MHz) NMR spectra have been obtained on a Bruker WB 400 spectrometer using a MAS DVT BL2.5 X/ $\mathrm{F} / \mathrm{H}$ trible resonance probehead. Samples were carefully packed in $2.5 \mathrm{~mm}$ diameter cylindrical zirconia rotors with Kel-F endcaps. Samples were spun at the magic angle at rates of $25 \mathrm{kHz}$ and the experiments were carried out at ambient probe temperature.

Typical parameters for single pulse ${ }^{19} \mathrm{~F}$ MAS NMR spectra were: spectral width, $75 \mathrm{KHz}$; pulse width, $2.5 \mu$ s; recycle delay, $10 \mathrm{~s}$; scans, 128; and spin rate, $25 \mathrm{kHz}$.

The typical acquisition parameters $19 \mathrm{~F}\{1 \mathrm{H}\}$ MAS were: spectral width, $75 \mathrm{kHz}$; recycle delay, $10 \mathrm{~s}$; pulse width, $2.5 \mu \mathrm{s}$ and proton decoupling field strength of $100 \mathrm{kHz}$ by SPINAL-64 
sequence; recycle delay, $10 \mathrm{~s}$; acquisition time, $25 \mathrm{~ms}$; 128 scans; and spin rate, $25 \mathrm{kHz}$.

The ${ }^{19} \mathrm{~F}$ spectra were referenced to ammonium trifluoroacetate sample and then the chemical shifts were recalculated to the $\left.\mathrm{CFCl}_{3}\left[\delta\left(\mathrm{CF}_{3} \mathrm{COONH}_{4}{ }^{+}\right)\right]=-72.0 \mathrm{ppm}\right)$

\section{Supporting Information}

Variable temperature ${ }^{1} \mathrm{H}$ NMR spectra, ${ }^{13} \mathrm{C},{ }^{15} \mathrm{~N},{ }^{19} \mathrm{~F}$ solid state NMR spectra; Table $\mathrm{S} 1$ containing calculated and some experimental ${ }^{1} \mathrm{H},{ }^{13} \mathrm{C}$ and ${ }^{15} \mathrm{~N}$ chemical shifts $(\delta$, ppm) of compounds 3a to 6a; Geometry ( $\AA$ ), energy (hartree) and number of imaginary frequencies of the different tautomers calculated at the B3LYP/6-311++G(d,p) computational level.

\section{Supporting Information File 1}

Additional material.

[http://www.beilstein-journals.org/bjoc/content/ supplementary/1860-5397-9-253-S1.pdf]

\section{Acknowledgements}

This work has been financed by the Spanish MICINN (CTQ2009-13129-C02-02 and CTQ2010-16122) and by the Comunidad Autónoma de Madrid (Project MADRISOLAR2, ref S2009/PPQ-1533).

\section{References}

1. Claramunt, R. M.; Alkorta, I.; Elguero, J. Comput. Theor. Chem. 2013, 1019, 108-115. doi:10.1016/j.comptc.2013.07.002

2. Hamor, T. A.; Martin, I. L. The Benzodiazepines. In Progress in Medicinal Chemistry; Ellis, G. P.; West, G. B., Eds.; Elsevier: Amsterdam, 1983; Vol. 20. doi:10.1016/S0079-6468(08)70219-4

3. Müller, W. E. The Benzodiazepine Receptor: Drug Acceptor only for a Physiologically Relevant Part of our Central Nervous System; Cambridge University Press: Cambridge, UK, 1987.

4. Squires, R. F., Ed. GABA and benzodiazepine receptors; CRC Press: Boca Raton, Florida, USA, 1987; Vol. I, II.

5. Trimble, M.; Hindmarch, I., Eds. Benzodiazepines; Wrightson Biomedical Publishing Ltd.: Petersfield, UK, 2000.

6. Berna, M. J.; Jensen, R. T. Curr. Top. Med. Chem. 2007, 7, 1211-1231. doi:10.2174/156802607780960519

7. Saber, A.; Zouihri, H.; Essassi, E. M.; Ng, S. W. Acta Crystallogr., Sect. E: Struct. Rep. Online 2010, 66, o1408. doi:10.1107/S1600536810017885

8. Allen, F. H. Acta Crystallogr., Sect. B 2002, 58, 380-388. doi:10.1107/S0108768102003890

9. Allen, F. H.; Motherwell, W. D. S. Acta Crystallogr., Sect. B 2002, 58, 407-422. doi:10.1107/S0108768102004895

10. Akkurt, M.; Kennedy, A. R.; Younes, S. H. H.; Mohamed, S. K.; Abdelhamid, A. A. Acta Crystallogr., Sect. E: Struct. Rep. Online 2012, 68, o3356. doi:10.1107/S160053681204651X
11. Mannschreck, A.; Rissmann, G.; Vögtle, F.; Wild, D. Chem. Ber. 1967, 100, 335-346. doi:10.1002/cber.19671000138

12. Polshettiwar, V.; Varma, R. S. Tetrahedron Lett. 2008, 49, 397-400. doi:10.1016/j.tetlet.2007.11.017

13. Vaddula, B. R.; Varma, R. S.; Leazer, J. Tetrahedron Lett. 2013, 54, 1538-1541. doi:10.1016/j.tetlet.2013.01.029

14. Okovytyy, S. I.; Sviatenko, L. K.; Gaponov, A. A.; Kasyan, L. I.; Tarabara, I. N.; Leszczynski, J. Eur. J. Org. Chem. 2010, 280-291. doi:10.1002/ejoc.200900689

15. Benasi, R.; Lazzeretti, P.; Taddei, F.; Nardi, D.; Tajana, A. Org. Magn. Reson. 1976, 8, 387-388. doi:10.1002/mrc.1270080715

16. Chidichimo, G.; Longeri, M.; Menniti, G.; Romeo, G.; Ferlazzo, A. Org. Magn. Reson. 1984, 22, 52-54. doi:10.1002/mrc.1270220111

17. Bernardini, A.; Viallefont, P.; Essassi, E. M.; Zniber, R. Org. Magn. Reson. 1982, 18, 134-137. doi:10.1002/mrc.1270180304

18. Berger, S.; Braun, S.; Kalinowski, H.-O. NMR Spectroscopy of the Non-Metallic Elements; John Wiley \& Sons: Chichester, UK, 1997; p 617.

19. Mallory, F. B.; Mallory, C. W. J. Am. Chem. Soc. 1985, 107, 4816-4819. doi:10.1021/ja00303a002

20. Alkorta, I.; Elguero, J. Int. J. Mol. Sci. 2003, 4, 64-92. doi:10.3390/i4030064

21. MNova program by Mestrelab Research (http://www.mestrec.com) running under Windows XP

22. Pecul, M.; Sadlej, J.; Leszczynski, J. J. Chem. Phys. 2001, 115, 5498-5506. doi:10.1063/1.1398099

23. Fonseca, T. A. O.; Ramalho, T. C.; Freitas, M. P. Magn. Reson. Chem. 2012, 50, 551-556. doi:10.1002/mrc.3837

24. Sammes, M. P.; Ho, K.-W.; Katritzky, A. R. Magn. Reson. Chem. 1985, 23, 720-724. doi:10.1002/mrc.1260230908

25. García-Frutos, E. M.; Gómez-Lor, B.; Monge, Á.; Gutiérrez-Puebla, E.; Alkorta, I.; Elguero, J. Chem.-Eur. J. 2008, 14, 8555-8561. doi:10.1002/chem.200800911

26. Alkorta, I.; Elguero, J.; Roussel, C. Tetrahedron: Asymmetry 2011, 22 , 1180-1183. doi:10.1016/j.tetasy.2011.06.010

27. Paizs, B.; Simonyi, M. Chirality 1999, 11, 651-658. doi:10.1002/(SICI)1520-636X(1999)11:8<651::AID-CHIR7>3.0.CO;2-5

28. 'SHELX97, Program for Refinement of Crystal Structure'; University of Göttingen: Göttingen, Germany, 1997.

29. Becke, A. D. Phys. Rev. A 1988, 38, 3098-3100. doi:10.1103/PhysRevA.38.3098

30. Becke, A. D. J. Chem. Phys. 1993, 98, 5648-5652. doi:10.1063/1.464913

31. Lee, C.; Yang, W.; Parr, R. G. Phys. Rev. B 1988, 37, 785-789. doi:10.1103/PhysRevB.37.785

32. Hariharan, P. C.; Pople, J. A. Theor. Chim. Acta 1973, 28, 213-222. doi:10.1007/BF00533485

33. Ditchfield, R.; Hehre, W. J.; Pople, J. A. J. Chem. Phys. 1971, 54, 724-728. doi:10.1063/1.1674902

34. Frisch, M. J.; Pople, J. A.; Binkley, J. S. J. Chem. Phys. 1984, 80, 3265-3269. doi:10.1063/1.447079

35. Ditchfield, R. Mol. Phys. 1974, 27, 789-807. doi:10.1080/00268977400100711

36. London, F. J. Phys. Radium 1937, 8, 397-409. doi:10.1051/jphysrad:01937008010039700 
37. Gaussian 09, Revision A.1, Frisch, M. J.; Trucks, G. W.; Schlegel, H. B.; Scuseria, G. E.; Robb, M. A.; Cheeseman, J. R.; Scalmani, G.; Barone, V.; Mennucci, B.; Petersson, G. A.; Nakatsuji, H.; Caricato, M.; Li, X.; Hratchian, H. P.; Izmaylov, A. F.; Bloino, J.; Zheng, G.; Sonnenberg, J. L.; Hada, M.; Ehara, M.; Toyota, K.; Fukuda, R.; Hasegawa, J.; Ishida, M.; Nakajima, T.; Honda, Y.; Kitao, O.; Nakai, H.; Vreven, T.; Montgomery, Jr., J. A.; Peralta, J. E.; Ogliaro, F.; Bearpark, M.; Heyd, J. J.; Brothers, E.; Kudin, K. N.; Staroverov, V. N.;

Kobayashi, R.; Normand, J.; Raghavachari, K.; Rendell, A.; Burant, J. C.; Iyengar, S. S.; Tomasi, J.; Cossi, M.; Rega, N.; Millam, N. J.; Klene, M.; Knox, J. E.; Cross, J. B.; Bakken, V.; Adamo, C.; Jaramillo, J.; Gomperts, R.; Stratmann, R. E.; Yazyev, O.; Austin, A. J.; Cammi, R.; Pomelli, C.; Ochterski, J. W.; Martin, R. L.; Morokuma, K.; Zakrzewski, V. G.; Voth, G. A.; Salvador, P.; Dannenberg, J. J.; Dapprich, S.; Daniels, A. D.; Farkas, Ö.; Foresman, J. B.; Ortiz, J. V.; Cioslowski, J.; Fox, D. J. Gaussian, Inc., Wallingford CT, 2009.

38. Silva, A. M. S.; Sousa, R. M. S.; Jimeno, M. L.; Blanco, F.; Alkorta, I.; Elguero, J. Magn. Reson. Chem. 2008, 46, 859-864. doi:10.1002/mrc.2272

39. Blanco, F.; Alkorta, I.; Elguero, J. Magn. Reson. Chem. 2007, 45, 797-800. doi:10.1002/mrc.2053

40. DuBois Murphy, P. J. Magn. Reson. 1983, 52, 343-345. doi:10.1016/0022-2364(83)90209-3

41. DuBois Murphy, P. J. Magn. Reson. 1985, 62, 303-308. doi:10.1016/0022-2364(85)90063-0

42. Alemany, L. B.; Grant, D. M.; Alger, T. D.; Pugmire, R. J. J. Am. Chem. Soc. 1983, 105, 6697-6704. doi:10.1021/ja00360a025

\section{License and Terms}

This is an Open Access article under the terms of the Creative Commons Attribution License (http://creativecommons.org/licenses/by/2.0), which permits unrestricted use, distribution, and reproduction in any medium, provided the original work is properly cited.

The license is subject to the Beilstein Journal of Organic Chemistry terms and conditions:

(http://www.beilstein-journals.org/bjoc)

The definitive version of this article is the electronic one which can be found at: doi:10.3762/bjoc. 9.253 